\title{
Tasarım Eğitiminde Sanat Eğitimi Üzerine Karşılaştırmalı Bir İnceleme ve Öneriler
}

\author{
${ }^{1}$ Pınar ÇINAR
}

\section{ÖZET}

Eleştirel düşünme, analitik düşünme, yaratıcı düşünme, sorun çözme, çözümleme, bireşim, değerlendirme gibi becerileri kapsayan üst düzey düşünme becerisinin kazanılmasında sanat eğitimi önemli bir konuma sahiptir. Yükseköğretim düzeyinde moda tasarımı eğitimiyle üst düzey düşünme becerisine sahip tasarımcılar yetiştirilmesi hedeflenmektedir. Türkiye'de lisans düzeyinde moda tasarımı programlarında verilen sanat eğitimini, yurtdışında moda tasarımı lisans programlarında verilen sanat eğitimiyle karşılaştırarak, sektörde çalışan moda tasarımı lisans düzeyi mezunların sanat eğitimine ilişkin görüşleriyle değerlendirmek ve moda tasarımı alanı sanat eğitimi derslerine yönelik öneriler geliştirmek çalışmanın amacını oluşturmaktadır. Bu amaçla, Türkiye ve yurtdışında lisans düzeyi moda tasarımı programlarında verilen sanat eğitimi dersleri incelenmiş, sektörde çalışan lisans mezunu 35 katılımcıdan sanat eğitimi derslerine ilişkin görüş alınmıştır. Program incelemelerinin analizinde betimsel analizden yararlanılmıştır. Mezun görüşlerinin analizinde ise ölçme formuyla toplanan verilere frekans, yüzde dağılım, çoklu cevap analizi temelinde tanımlayıcı istatistik uygulanmıştır. Türkiye ve yurtdışında moda tasarımı lisans programlarında verilen sanat eğitimi derslerine ilişkin gerçekleştirilen inceleme ve sektörde çalışan mezunların görüşleri sonucunda profesyonellerin ve sektörün paydaş olacağı proje, saha uygulamaları, staj, teknik gezi ve etkinlikler ile yapılandırılmış, uygulama ve etkinlik ağırlıklı sanat eğitimi önerisi getirilmiştir.

Anahtar Kelimeler: Tasarım, moda tasarımı, sanat eğitimi, moda tasarımında sanat eğitimi.

\section{A Comparative Study and Suggestions on Art Education in Design Education}

\begin{abstract}
Art education has an important place in the acquisition of high-level thinking skills, including skills such as critical thinking, analytical thinking, creative thinking, problem solving, analysis, synthesis, and evaluation. It is aimed to train designers with high-level thinking skills with fashion design education at the higher education level. To compare the art education in bachelor's degree in fashion design program in Turkey with the arts education in overseas fashion design degree program, to get sector workers' views abouth arts education given fashion design undergraduate level and develop suggestions for art education courses for the fashion design, is the objective of the study. For this purpose, were examined art education courses in the fashion design degree program in Turkey and abroad and were views on the courses art education from 35 participants of workers in the sector graduated fashion design. Descriptive analysis was used in the analysis of the program reviews. In the analysis of graduate opinions, descriptive statistics were applied on the basis of frequency, percentage distribution, and multiple response analysis on the data collected with the measurement form. Turkey and abroad, the review undertaken in given arts education in fashion design degree program and the results of the views of graduates working in the sector, projects of professionals and sectors of the stakeholders, field applications, configured with technical visits and events, practices and activities mainly an arts education has been proposed.
\end{abstract}

Keywords: Design, fashion design, art education, art education in fashion desin

\section{GíRiş}

Üst düzey düşünme; bilgiler arasında tutarlılık, bağlantı ve kapsamlı zihinsel etkinlikler gerektiren, araştırma ve sorgulamaya dayalı, sonuçların bilimsel verilere dayandırılarak sunulduğu düşünme biçimidir (Aslan, 2012). Eleştirel, analitik, ilişkisel, yaratıcı düşünme, sorun çözme, çözümleme, bireşim, değerlendirme gibi beceriler en çok bilinen üst düzey düşünme becerileri arasindadır (Aslan, 2011: 238).

\footnotetext{
${ }^{1}$ Sorumlu Yazar: Öğr. Gör. Dr., Sakarya Uygulamalı Bilimler Üniversitesi, Ferizli Meslek Yüksekokulu-Tasarım Bölümü, pcinar@subu.edu.tr, ORCID: 0000-0001-5187-0063
} 
Moda tasarımcıs1, eleştirel düşünme ve problem çözme yetkinliği yüksek, estetik algıs1 gelişmiş, araştırma süreçlerini yürütebilen, alanın gerektirdiği bilgi ve beceriye sahip, yeni, yaratıcı, özgün tasarımlar yapabilen ve bu tasarımlarını ürün haline getirebilen kişi olarak tanımlanmaktadır (Bilgen, 2002; Çivitçi, 2004; Tansoy vd. 1994).

Bugün, bilimsel araştırma süreçlerini bilen, hedef kitlenin gereksinimlerine uygun, yeni, yaratıcı, estetik, özgün giysiler tasarlayan ve tasarımlarını üretebilme bilgi ve becerisine sahip olan moda tasarımcısının yetiştirilmesinde üniversiteler, Türkiye'de moda tasarımı alanında eğitim veren başlıca kurumlar arasında yer almaktadır. 2018 yılı Öğrenci Seçme ve Yerleştirme Merkezi (OSYM) Klavuzu'na göre, moda tasarımı eğitimi veren 31 lisans programı bulunmaktadır. 31 lisans programının 15'i devlet, 16's1 vakıf üniversitesindedir.

Üniversitelerin, moda tasarımı-moda ve tekstil tasarımı lisans öğretim programları incelendiğinde, programda yer alan derslerin dört ana grupta toplandığ 1 görülmektedir. İlk grupta temel dikim ve kalıp bilgisinin kazanıldığı dersler, ikinci grupta tasarım bilgisini ve tasarımc1 kişiliğini geliştirmeyi amaçlayan sanat eğitimi dersleri, üçüncü grupta, üretim işletme, pazarlama bilgisini geliştiren dersler ve son grupta tüm öğrenimlerini sentezlediği sunum, proje ve koleksiyon hazırlama dersleri yer almaktadır.

Yurtdışında moda tasarımı eğitimi çeşitli ülkelerde farklılık göstermekle birlikte iki yıllık meslek yüksekokullarında ya da üç-dört y1llık yüksekokullarda verilmektedir. Moda endüstrisinin küresel pazarda söz sahibi olduğu ülkelerde (ör. Fransa, ABD, İngiltere, İtalya vb.) moda endüstrisinin ihtiyaç duyduğu nitelikli elemanı yetiştirmek üzerine uzmanlaşmış özel üniversiteler ve yüksekokullar mevcuttur. Bunlardan, İngiltere' de Saint Martin Sanat ve Tasarım Okulu (Central Saint Martins College of Art and Design), Londra Moda Koleji (London College of Fashion) ve Kraliyet Sanat Koleji (Royal College of Arts); ABD'de Parsons Tasarım Okulu (Pratt Institute, Parsons The New School of Design) ve Moda Teknoloji Enstitüsü (The Fashion Institute of Technology) öne çıkar. Mezunlarının ve öğretim elemanlarının özel sektörle ilişki içinde bulundukları bu kurumların, moda pazarının başarısını olumlu yönde etkilediği söylenebilmektedir (İsözen, 2009).

Yurtdışında moda tasarımı eğitimi veren okulların eğitim programları incelendiğinde Alman devlet okulu Bauhaus'un öğretim modelinin etkili olduğu görülür. Bauhaus'un, çalışma dünyasına yaratıcı kişiler olarak katılabilen sanatçı ve tasarımcılar yetiştirmek için; sanatsal ve pratik pedagoji entegrasyonu, estetik ve uygulamalı becerileri kazandırmadaki "yaparak (by doing and making)" öğrenme modeli, sanat ve tasarım alanında yükseköğrenimde, Amerika gibi pek çok ülkeyi güçlü bir şekilde etkilemiştir (Marshall, 2009, Wax, 2010). Bu eğitimi sağlamak için fakültelerde, sanatçı ve tasarımcılarla, pratikte işlerin nasıl yapıldığı uygulamalarına yer verildiği ve böylece uzmanlıkların kazandırıldığı çalışmalar etkindir.

21. yüzyılda yaratıcı, esnek, farklı şartlara ve küresel dünyaya uyum sağlayabilen, yenilikçi iş gücüne duyulan ihtiyaç giderek artmaktadır. Toplumda yaratıcılık ve yenilikçiliğin tetiklenmesinin yanı sıra, ülkelerin yaratıcı ve kültürel sermayesinin gelişmesi ve büyümesi yolunda sanat eğitimi politikalarına daha fazla önem verilmektedir (Ece ve Fazlığlu, 2015).

Moda ve tekstil tasarımı eğitimi veren kurumlar da sektöre sağladığı işgücü, araştırma geliştirme süreçlerindeki işbirlikleri, modanın toplumsal bağlamları hakkındaki araştırmalarıyla bu dönüşümün bir parçası olarak görülmektedir. Bu bağlamda moda ve tekstil tasarımı eğitiminde uluslararası standartlara ulaşmak, sektörde yaşanan değişime katkı sağlamak, ülke ekonomisi ve imajını güçlendirmeye yönelik faaliyetlere katkı sunmak için moda ve tekstil tasarımı eğitimi gözden geçirilmelidir (Akt: Aygül ve Özüdoğru, 2014).

Moda ve tekstil sektörünün ihtiyaç duyduğu, estetik, yaratıcı, özgün, yenilikçi, tasarım bilgisi ve gücü yüksek moda tasarımcısının yetiştirilmesi, üniversitelerin moda tasarımı programlarında 
verilecek nitelikli bir sanat eğitimi ile mümkündür (Buyurgan ve Buyurgan, 2012). Bireyin yeteneklerini ve yaratıcılık gücünü geliştirerek, duygu, düşünce ve izlenimlerini estetik bir düzeyde anlatabilmesini sağlamak amacı ile yapılan tüm eğitim çabasına 'sanat eğitimi' denir (Artut, 2001).

Sanat eğitimi, okul içindeki ve dışındaki eğitimin vazgeçilmez bir parçasıdır. Sanat eğitimi: kültürel okuryazarlık, yaratıcılık ve yaratıcı düşünme yeteneklerinin gelişmesine, bilişsel ve duyuşsal öğrenmeye, estetik duyarlılığın (eleştiri) ve sanatsal yeteneklerin kazanılmasına ve sanat pratiklerinin öğrenilmesine katkıda bulunur (Ece ve Fazlıoğlu, 2015).

Sanat eğitimi, kişiye duygu, düşünce ve izlenimlerini anlatabilmesi, yetenek ve yaratıcıllğını estetik bir seviyeye ulaştırabilmesi, estetik yargı yapabilmesi konusunda yardımcı olmayı amaçlarken, gözlem yapma, özgün buluş, pratik düşünceyi, bireyin el becerisini geliştirir ve bireşim yapmasına yardımcı olur. Var olanları yineleyen değil, yeni olanı yapabilme yeterlilikleri olan insanları yetiştirmeyi hedefleyen sanat eğitimi sürecinde; algılama, bilgilenme, düşünme, tasarlama, yorumlama, ifade etme, eleştirme davranışları, estetik ilkeler doğrultusunda sanatların dili kullanılarak öğrenilir (Küçüktepepınar, 2014).

Gökay (2004)'a özellikle giyim ve aksesuarlar üzerine odaklanan moda tasarımında, yaratıcı düşünce yeteneğinin yeterince gelişmiş olması iyi bir moda tasarımcısı veya endüstriyel tasarımcı için önemlidir. Buyurgan (2012), Ece ve Fazlıŏlu (2015), Gökay (2004)'ün çalışmaları eleştirel düşünme, analitik düşünme, yaratıcı düşünme, sorun çözme, çözümleme, bireşim, değerlendirme gibi üst düzey düşünme becerilerine sahip moda tasarımcısı ve nitelikli bir moda tasarımı eğitimi için, etkili bir sanat eğitiminin önemini ortaya koymaktadır. Bu bilgiden hareketle, Türkiye'de lisans düzeyinde moda tasarımı programlarında verilen sanat eğitimini, yurtdışında moda tasarımı lisans programlarında verilen sanat eğitimiyle karşılaştırarak, sektörde çalışan moda tasarımı lisans düzeyi mezunların sanat eğitimine ilişkin görüşleriyle değerlendirmek ve moda tasarımı alanına yönelik sanat eğitimi önerisi geliştirmek çalışmanın amacını oluşturmaktadır.

\section{YÖNTEM}

\subsection{Araştırma Modeli}

Bu araştırma, Türkiye' de moda tasarımı lisans programlarında verilen sanat eğitiminin, yurtdışında verilen sanat eğitimi ile karşılaştırılması ve sektörde çalışan moda tasarımı lisans düzeyi mezunların sanat eğitimine ilişkin görüşlerinin değerlendirilmesiyle, moda tasarımı alanına yönelik sanat eğitimi önerisi geliştirilmesini amaçlayan nitel araştırma deseninde tarama modelinde bir çalı̧̧madır. "Nitel araştırma, gözlem, görüşme, doküman analizi gibi nitel veri toplama yöntemlerinin kullanıldığı, algıların ve olayların doğal ortamda gerçekçi ve bütüncül bir biçimde ortaya konmasına yönelik nitel bir sürecin izlendiği” araştırma olarak tanımlanmaktadır (Yıldırım ve Şimşek, 2008: 19). Tarama modeli geçmişte varolmuş veya halen varolan bir durumu, olay nesne ve bireylere müdahalede bulunmadan oldukları gibi tanımlamaya çalışan bir yaklaşımdır (Karasar, 2005: 183). Çalışmanın amacına yönelik olarak, Türkiye'de ve yurtdışındaki üniversitelerin moda tasarımı lisans programlarında verilen sanat eğitimi dersleri incelenmiş, moda tasarımı lisans düzeyi mezunlara uygulanan görüş formuyla sanat eğitimine ilişkin görüşleri alınmış ve yapılan değerlendirmeyle moda tasarımı alanına yönelik sanat eğitimi önerisi getirilmiştir. Mezun görüşlerinin alınmasında lisans düzeyinde 35 mezuna ulaşılmıştır. Mezunlardan elde edilen araştırma verilerinin çözümlenmesinde, ölçme formuyla toplanan verilere frekans, yüzde dağılım, çoklu cevap analizi temelinde tanımlayıcı istatistik uygulanmıştır. Çalışma bulgularıyla moda eğitiminin bugünü ve geleceği açısından alan uzmanlarına veri sağlaması yönüyle önemlidir.

\section{2. Çalışma Grubu}

Türkiye'deki moda tasarımı lisans düzeyi mezun görüşlerini almak üzere moda tasarımı programı mezunlarından oluşan çalışma grubu belirlenmiştir. Mezun çalışma grubunun belirlenmesinde kartopu örnekleme yöntemi kullanılmıştır. Bu yöntem araştırmanın problemine 
ilişkin zengin bilgi kaynağı olabilecek birey veya durumların saptanmasında etkilidir. Süreç ilerledikçe isimler veya durumlar bir kartopu gibi büyüyerek devam eder, belirli bir süre sonra aynı isimler veya durumlar öne çıkmaya başlar, bu durum araştırmacının yeterli örnekleme ulaştığına işaret eder (Yıldırım ve Şimşek, 2008: 107).

Mezun çalışma grubunda yer alan moda tasarımı mezunlarının eğitim düzeyi, mezun olunan üniversite, çalıştıği sektör, iş tecrübesi ve iş pozisyonu bilgileri demografik özelliklerini oluşturmaktadır. Araştırmaya on üç üniversiteden mezun 35 katılımcı katkı sağlamıştır. En yüksek katılım, Ankara Hacı Bayram Veli Üniversitesi mezunu 9; Marmara Üniversitesi mezunu 8 kişi ile olmuştur. İstanbul Teknik ve Mimar Sinan GSÜ mezunu 3; Eskişehir Teknik, İstanbul Aydın ve Nişantaşı Üniversitesi' nden 2'şer mezun katılım sağlamıştır. Dokuz Eylül, Giresun, Işık, İstanbul Arel, İstanbul Gelişim ve Selçuk Üniversitesi mezunlarından 1'er kişi katılmıştır.

Mezun çalışma grubunun iş tecrübesi için, 1-4, 5-9, 10-14, 15-19, 20 ve üstü olarak beş sinıf belirlenmiştir. Araştırmaya katılan mezunların \% 37.1' inin 1-4 ve 5-9 yıl iş tecrübesine sahip oldukları görülmüştür. Mezun çalışma grubunun iş tecrübesi dağılımı oranlarının 10-14 yıl \% 11.4, $15-19$ yıl \% 8.6, 20 yıl ve üstü \% 5.7 olduğu belirlenmiştir.

İş pozisyonu için katılımcıların verdikleri yanıtlar sonucunda on üç sınıf oluşturulmuştur. Bunlar, modelist, imalatçı, stilist, yardımcı tasarımcı, uzman tasarımcı, modelhane şefi, numune uzmanı, eğitim sorumlusu, yıkama uzmanı, laborant, ürün teknoloğu, müşteri temsilcisi ve maliyet uzmanı' dır. Mezun çalışma grubunun iş pozisyonuna göre dağılımında en yüksek katılımın \% 20 uzman tasarımcı, \% 14.3 stilist, yardımcı tasarımcı, eğitim sorumlusu olarak çalışanlardan oluştuğu görülmüştür.

\section{BULGULAR}

\subsection{Yurtdışında Lisans Düzeyinde Moda Eğitimi Veren Üniversiteler}

Yurtdışında lisans düzeyinde moda eğitimi veren okul belirlemesinde, akademik deneyim temel alınmıştır. Kökleri 1900'lü yılların başına kadar uzanan, Moda Teknoloji Enstitüsü (Fashion Institute of Technology-New York), Saint Martins Sanat ve Tasarım Koleji (Central Saint MartinsLondra), ESMOD (Paris), Marangoni Enstitüsü (Instituto Marangoni-Milano) ve Bunka Moda Koleji (Bunka Fashion Collage-Tokyo) incelenecek okullar olarak belirlenmiştir. Belirlenen okulların, "CEOWORLD MAGAZINE", "The Business of Fashion", "Fashionista" vb. yayın ve kuruluşların, 2018 yılı için gerçekleştirdikleri, işe yerleştirme oranı, işveren geribildirimi, akademik deneyim, küresel itibar, öğrenci ve mezun geribildirimi, mezun başarısı, uzmanlaşma gibi kalite göstergelerine dayanan anket sonuçlarına göre, dünyadaki en iyi moda okul belirlemeleri içerisinde ilk on arasında yer aldıkları görülmektedir.

Moda Teknoloji Enstitüsü (Fashion Institute of Technology-FIT) Amerika'nın New York eyaletinde bulunmaktadır. 1940'larda Mortimer C. Ritter ve Max Meyer'in hazır giyim endüstrisi için okul düzenlemeye karar vermelerinin ardından, ilk olarak, eğitimi teşvik etmek için "Giyim Endüstrisi Eğitim Vakfı” nı kurarlar. New York Eyaleti Yönetim Kurulu'ndan “Teknoloji ve Moda Tasarım Enstitüsü” kurmak için tüzük alan vakıf, 1944 yılında 100 öğrenci ile açılır. Okul 1957 yılında akreditasyon alarak müfredat ve öğrenci kapasitesini büyütür. Bugün okul 10.000'den fazla öğrenciye farklı derecelerde Moda Tasarımı, Erkek Giyim, Kozmetik ve Parfüm Pazarlama, Moda İşletmeciliği, Görsel Sunum ve Sergi Tasarımı gibi programlarda eğitim vermektedir. Moda Tasarımı lisans düzeyindeki (Undergraduate/Baccalaureate) eğitim süresi sekiz yarıyıldır. Lisans eğitimi, iki yılın sonunda iç giyim, örgü, spor giyim, çocuk giyim gibi alanlara ayrılıp uzmanlaşmaya dayalıdır (hhtp1).

Saint Martins Sanat ve Tasarım Koleji (Central Saint Martins), 1896 yılında kurulan Sanat ve Tasarım Okulu ve 1854 yılında kurulan Saint Martins Sanat Okulu'nun, 1989 yılında birleşmesiyle 
kurulmuştur. Londra Eğitim Otoritesi tarafından sanat, tasarım, moda ve medya okullarını bir araya getirmek için, 1986' da Londra Enstitüsü oluşturulmuş, enstitü 1988'de tüzel kişilik haline getirilmiştir. 2003 yılında üniversite statüsü verilmiş ve 2004 yılında ismi Londra Sanat Üniversitesi olarak değiştirilmiştir. Londra Sanat Üniversitesi, Saint Martins Sanat ve Tasarım Koleji ile birlikte Camberwell Sanat Koleji, Chelsea Sanat Koleji, Londra İletişim Fakültesi, Londra Moda Koleji, Wimbledon Sanat Koleji ve Yaratıcı Bilgi İşlem Enstitüsü'nün birleşimidir. Saint Martin' de moda eğitimi üç aşamada gerçekleşmektedir. Her aşama 120 kredidir. Birinci aşamayı tamamlayan "Yüksek Eğitim Sertifikası", ikinci aşamayı tamamlayan "Yükseköğretim Diploması" (Önlisans)ve üçüncü aşamayı tamamlayan "BA Fakülte Diploması" (Lisans) almaya hak kazanmaktadır. Saint Martins' de moda eğitimi, modaya özgü bir alanın derinlemesine incelenmesine dayalı beş farklı yol seçeneği sunmaktadır. Bu yollar: Moda Tasarımı Erkek Giyim, Moda Tasarımı Kadın Giyim, Moda Baskı, Triko Moda Tasarımı, Moda Tasarımı Pazarlama'dır (http2).

ESMOD adını, on dokuzuncu yüzyılda İmparotoriçe Eugenie' nin usta terzisi olan Alexis Lavigne'den almaktadır. Alexis Lavigne 1841 yılında ESMOD okulunun ilki olan "Lavigne Kesim Kursları" nı açmıştır. 1880'de Lavigne'nin ölümü üzerine kızı Alice Guerre okulun yönetimini devralmıştır. 1976'da Ecole Guerre-Lavigne "ESMOD” adını almıştır. ESMOD günümüzde on dört ülkede yirmi iki okul sayısına ulaşmıştır. ESMOD' da “Moda Tasarımı ve Yaratımı” lisans eğitimi üç yıl sürmektedir. Her yıl iki sömestr ve 30 AKTS olup toplam 180 AKTS'dir. Moda Tasarımı ve Yaratımı lisans eğitiminde üçüncü yıl seçilen bir alanda uzmanlaşmaya dayalı olarak gerçekleşmektedir. Uzmanlık alanları: Kadın Giyim, Erkek Giyim, Çocuk Giyim, Plaj Giysileri, İç Giyim, Aksesuar, Örme Grubu gibi alanlardır (http3).

Marangoni Enstitüsü (Instituto Marangoni), 1935 yılında ünlü İtalyan modacı Giulio Marangoni tarafından, moda alanında uzmanlaşmış profesyonelleri ve teknisyenleri yetiştirmek üzere kurulmuş bir okuldur. Marangoni' de moda tasarımı eğitimi, önlisans seviyesinde iki yıl, lisans seviyesinde üç yıl olarak verilmektedir. İki yıl moda tasarımı eğitimi, kadın-erkek koleksiyon tasarımı ve giysi üretimi, kumaş geliştirmede yaratıcı fikirler, moda-sanat-tasarım materyal ve kumaşlarının analizi, eskiz ve çizim becerileri çalışmalarını içermektedir. İki yıl süren eğitimin sonunda uygunluk kriterleri karşılandığında, İtalya, Milano veya Floransa'daki Marangoni Enstitüsü okullarından birinde lisans tamamlama eğitimine devam edebilmektedir. Üç yıl süren moda eğitimin de ise üç yıla geçmeden önce bir yıl süren hazırlık yılında, moda, tasarım ve sanat alanında araştırma ve inceleme, alanda kullanılan materyallerin analizi, dikiş, tasarım çalışmalarını içeren eğitim verilmektedir (http4).

Bunka Moda Koleji (Bunka Fashion Collage), 1919 yılında Namiki Isaburo'nun Tokyo'da açtığı kadın ve çocuk mağazası, aynı zamanda da kadın ve çocuk terzilik okuludur. 1922'de Endo Seijiro'nun işbirliğiyle mağaza Bunka Dikiş Okulu olarak geliştirilir. 23 Haziran 1923'te, Tokyo Eğitim Yasası tarafından Japonya'nın ilk terzilik kurumu olarak onaylanır ve bu tarih okulun kuruluş yıldönümü kabul edilir. 1936 yılında okulun adı "Bunka Moda Koleji” olarak değiştirilir. 1969 yılında New York Moda ve Teknoloji Enstitüsü (FIT), 1988'de Pekin Moda Koleji Enstitüsü ile işbirlikleri ve 1990 yılında Çin "Donghua Üniversitesi" ile değişim anlaşması yapılır. Bunka Moda Koleji, "Moda Yaratım", "Moda Teknoloji”, "Moda Pazarlama ve Dağıtım" ve "Moda Aksesuar ve Tekstil” olmak üzere dört bölüme sahiptir. Moda Yaratım Bölümü, Giysi Yaratım Programı eğitim süresi iki yıl olup, önlisans eğitimine denktir. İki yıl eğitimi başarı ile tamamlayan öğrenci üçüncü yıl ileri kurs ile eğitimine devam edebilmektedir. Moda Teknoloji Bölümü, Yaratıcı Tasarım Programı'nda lisans derecesine eşdeğer diploma kursu sunulmaktadır. Yaratıcı Tasarım Programı eğitim süresi dört yıl olup, ilk yıl moda teknolojisinin temelleri eğitimi verilmektedir. İkinci ve üçüncü yıl "Yaratıcı Giyim Tasarımı", "Giysi Tasarım Tekniği”, "Endüstriyel Ticaret” ve "Triko Tasarımı" alanlarından birinde uzmanlaşmaya dayalı olarak eğitim devam etmektedir. Dördüncü yıl, sektörle işbirliği ve stajlar yoluyla uzmanlık bilgisi geliştirilmektedir (http5).

\subsection{Türkiye ve Yurtdışında Moda Tasarımı Lisans Eğitimi Veren Üniversitelerde Okutulan}




\section{PINAR CINAR / ISEC2021 Sakarya- Turkey \\ Zorunlu ve Seçimlik Sanat Eğitimi Dersleri ve AKTS Oranları}

Türkiye ve Yurtdışındaki moda tasarımı lisans programlarının ders planları incelenmiş, zorunlu ve seçimlik sanat eğitimi dersleri belirlenmiştir. Zorunlu ve seçimlik sanat eğitimi derslerinin belirlenmesinde dersin öğrenme kazanımlarının program yeterlikleri ile ilişkisinden yararlanılmıştır. Yaratıcılık, özgünlük, yenilik, estetik beğeni, eleştirel düşünme, sorun belirleme, çözüm üretme, analiz ve sentez gibi üst düzey yeterliklerin kazandırıldığı dersler "sanat eğitimi dersleri” olarak seçilmiştir.

Moda Teknoloji Enstitüsü'nde lisans düzeyinde verilen zorunlu sanat eğitimi derslerinin Görsel Tasarım Kavramları, Moda Sanat Stüdyosu, Moda Araştırmaları ve Esin, Batı Sanatı ve Medeniyeti, 21. Yüzyıl estetiği için 20. Yüzyıl Stili olduğu görülmektedir.

ESMOD lisans düzeyi zorunlu sanat eğitiminde Moda Tarihi ve Kültürü, Moda Illlüstrasyon, Renk Teorisi derslerini sunmaktadır.

Saint Martins Sanat ve Tasarım okulunda ise, Moda Tarihi ve Kültürü, Moda Kuramlarl ve Uygulamaları, Moda Yaklaşımları ve Araştırmaları dersleri verilmektedir.

Marangoni Enstitüsü zorunlu sanat eğitiminde, Moda Çizim Temelleri, Moda Tasarım Temelleri, Sanat ve Moda Araştırması, Sanat ve Tasarım Tarihi derslerini sunmaktadır.

Bunka Moda Koleji'nde lisans düzeyi moda eğitiminde, Batı Sanatı ve Medeniyeti, Desen, Moda Resmi, Batı Giyim Tarihi dersleri zorunlu sanat eğitimi dersleri olarak verilmektedir.

Türkiye'de lisans moda tasarımı-moda ve tekstil tasarımı eğitimi veren üniversitelerde verilen zorunlu sanat eğitimi dersleri incelendiğinde, Temel Sanat Ĕ̆itimi, Desen, Moda İllüstrasyonu, Sanat Tarihi, Moda Tarihi, Moda Resmi ve Temel Tasarım dersleri öne çıkmaktadır. Yapılan incelemelere göre Türkiye ve yurtdışında lisans düzeyi moda tasarımı eğitiminde verilen zorunlu sanat eğitimi derslerinin benzerlik gösterdiği söylenebilmektedir.

Yurtdışında moda tasarımı lisans eğitimi veren üniversitelerde okutulan seçimlik sanat eğitimi ders belirlemelerine yönelik incelemede, yalnızca Moda Teknoloji Enstitüsü' nün seçimlik sanat eğitimi dersi sunduğu görülmektedir. Türkiye'de lisans moda tasarımı-moda ve tekstil tasarımı eğitimi veren üniversitelerde okutulan seçimlik sanat eğitimi derslerine ilişkin yapılan incelemede ise öne çıkan derslerin, Moda İllüstrasyonu, Estetik, Sanat Sosyolojisi, Moda Tarihi, Görsel Algl, Kostüm Tarihi, Sanat Tarihi ve Uygarlık Tarihi olduğu görülmektedir.

Yurtdışında lisans moda tasarımı eğitimi veren üniversitelerde verilen zorunlu ve seçimlik ders sayılarını ve seçimlik ders AKTS'nin toplam AKTS' ye oranına ilişkin yapılan incelemede, Moda Teknoloji Enstitüsü zorunlu ve seçimlik ders sayı ve AKTS oranıyla moda eğitiminde sanat eğitimini önceleyen bir üniversite olarak belirlenmektedir. Saint Martins ve ESMOD’ da zorunlu sanat eğitimi ders sayısı 3, Marangoni Enstitüsü' nde 5 olup, bu okullarda seçimlik ders sunulmamaktadır. Bunka Moda Koleji' nde zorunlu sanat eğitimi ders sayısı 4 olup, seçimlik sanat eğitimi dersi bulunmamaktadır. Türkiye' lisans moda tasarımı-moda ve tekstil tasarımı eğitimi veren üniversitelerin zorunlu ve seçimlik ders sayıları ve AKTS oranlarına bakılarak, sanat eğitimini önceleyen üniversiteler olarak belirlenen, Eskişehir Teknik, Atılım, Dokuz Eylül, Ankara Hacı Bayram Veli, İstanbul Teknik, Mersin ve Uşak Üniversiteleri'nde en düşük sanat eğitimi ders sayısının 11 olduğu görülmektedir.

Zorunlu ve seçimlik sanat eğitimi sayıları ve AKTS oranları ile moda eğitiminde verilen sanat eğitimine ilişkin bir değerlendirme yapıldığında, Türkiye'de lisans moda eğitiminde verilen sanat eğitiminin, yurtdışında moda eğitiminde önde gelen üniversitelerden daha iyi yapılandırıldığına ilişkin bir resim oluşmaktadır. Ancak, yapılan incelemelerde, Türkiye'deki ve yurtdışındaki eğitim müfredatları arasında farklılıklar tespit edilmiştir. Yurtdışında moda tasarımı eğitimi müfredatı kadın giyim, erkek giyim, çocuk giyim, iç giyim, triko tasarım, moda pazarlama gibi alanlarda uzmanlaşmaya dayalı ve moda endüstrisi ağı, stajlar ve proje çalışmaları ile esnek ve kapsamlı bir 
öğretim sunmaktadır. Üniversitelerin çeşitli moda markaları ve moda tasarımcılarıyla işbirlikleri olup, eğitimin yaklaşı yüzde ellisini, öğrencilerin bu marka ve tasarımcılarla gerçekleştireceği proje çalışmaları ve stajlar oluşturmaktadır. Proje süreçleri içerisinde profesyonellerle gerçekleştirilen çalışmalar, araştırma ile öğrencilere, kişisel estetik, yaratıcılık ve özgünlüklerini ortaya koyup geliştirebilecekleri fursatlar sunmaktadır.

\subsection{Moda Tasarımı Alanı Mezun Görüşleri}

Moda tasarımı lisans düzeyi mezunlarının iş pozisyonlarının gerektirdiği yetkinlikler, alınan eğitimin bu yetkinlikleri kazandırma durumu ve sanat eğitiminin nasıl olması gerektiğine ilişkin görüşlerini değerlendirmek üzere mezun çalışma grubundan elde edilen bulgular bu bölümde yer almaktadır.

Moda tasarımı lisans düzeyi mezunların iş pozisyonlarının gerektirdiği yetkinlikler için verdikleri yanıtlar aşağıda verilmiştir.

Tablo 1. İş Pozisyonunun Gerektirdiği Temel Nitelikler Için Verilen Yanıtların Dağılımı.

\begin{tabular}{llc}
\hline Temel Nitelikler & \multicolumn{2}{c}{ Yanıtların } \\
Dağılımı \\
\hline Eleştirel olma & f & \% \\
Sorgulama & 22 & 7.7 \\
Özgünlük & 28 & 9.8 \\
Yenilik & 24 & 8.4 \\
Estetik algı & 32 & 11.2 \\
Sorun belirleme & 27 & 9.5 \\
Çözüm üretme & 23 & 8.1 \\
Yaratıcılık & 33 & 11.6 \\
Yorumlama & 29 & 10.2 \\
Değerlendirme & 30 & 10.5 \\
Diğer & 30 & 10.5 \\
Toplam & 7 & 2.5 \\
\hline
\end{tabular}

*Katılımcılar birden fazla seçenek işaretleyebildiklerinden, frekanslar çoklu cevap setine göre alınmış ve verilen toplam cevaba göre oranlanmıştır.

Lisans düzeyi mezunların iş pozisyonunun gerektirdiği temel nitelikler için verdikleri yanıtların dağılımı incelendiğinde en yüksek oran \% 11.6 ile çözüm üretme, $\% 11.2$ ile yenilik, \% 10.5 ile yorumlama ve değerlendirme, \% 10.2 ile yaratıcılık niteliklerinin sıralandığ görülmektedir. Yanıtların \% 2.5'ini diğer yanıtı oluşturmaktadır. Araştırmaya katılan mezunların diğer seçeneğine verdikleri yanıtar işlem hızı, disiplin, objektiflik, liderlik, iletişim ve analitik düşünme olarak ifade edilmektedir. Mezunların iş pozisyonlarının gerektirdiği temel nitelikler için verdikleri yanıtlar, 
sektörün üst düzey düşünme becerilerine sahip nitelikte çalışanlara gereksinim duyduğuna işaret etmektedir.

Tablo 2. Lisans düzeyinde alınan eğitimin işin gerektirdiği yeterlikleri kazandırma durumuna ilişkin verilen yanıtların dağılımı.

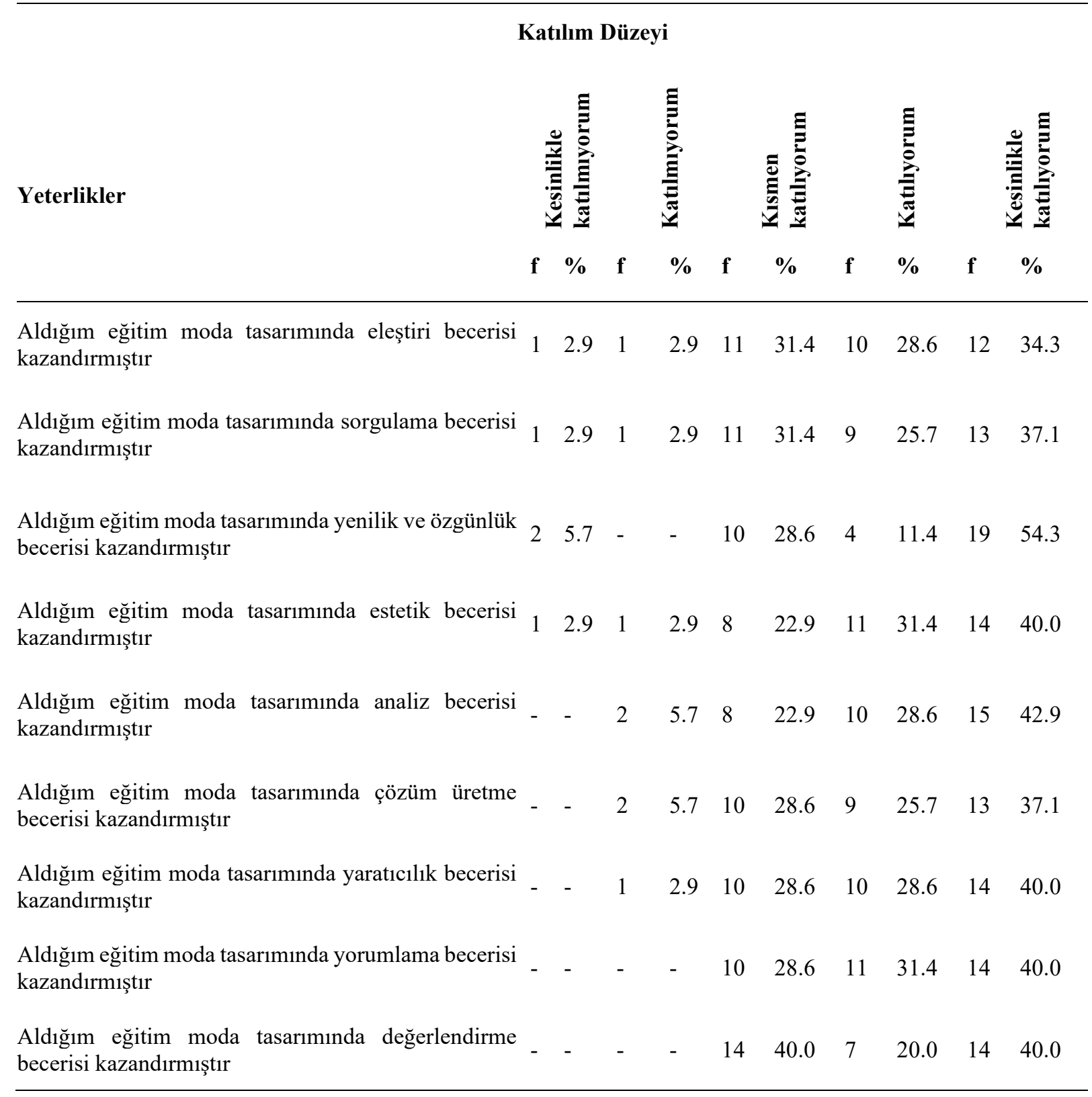

Alınan eğitimin işin gerektirdiği yeterlikleri kazandırma durumuna ilişkin verilerin dağılımı incelendiğinde lisans düzeyi mezunlar en yüksek oran \% 54 ile yenilik ve özgünlük yeterliğinin kazandırıldığı görüşündedir.

Araştırmaya katılan mezunlar iş pozisyonunun gerektirdiği çözüm üretme, yenilik, yorumlama, değerlendirme ve yaratıcılık, yeterliklerinin alınan eğitim ile kazandırıldığını ifade etmektedir.

Tablo 3. Moda tasarımında sanat eğitiminin daha etkili ve yeterli hale getirilebilmesi için neler yapılabilir? sorusuna verilen yanıtların dağılımı. 


\begin{tabular}{|c|c|}
\hline Değişkenler & $\begin{array}{l}\text { Dağılımı } \\
\text { f }\end{array}$ \\
\hline 1.Moda tasarımcılarının deneyimlerini paylaşacakları eğitim ortamları yaratılmalı & 1 \\
\hline 2.Tasarımların analizi çalışmalarına yer verilmeli & 3 \\
\hline 3.Uygulamalı eğitime ağırlık verilmeli & 4 \\
\hline 4.Yeteneğe göre uzmanlaşmaya dayalı bir program yapısı oluşturulmalı & 3 \\
\hline 5.Güncel ders içerikleri oluşturulmalı & 5 \\
\hline 6.Bilgisayarlı tasarım program eğitimi verilmeli & 1 \\
\hline $\begin{array}{l}\text { 7.Daha fazla sanatsal uyaranla buluşabilecekleri müze, sanat galerisi vb. gezilere yer } \\
\text { verilmeli }\end{array}$ & 5 \\
\hline 8.Okul dışı staj, sektör, tasarımcı vb. işbirliğine dayalı eğitime yer verilmeli & 8 \\
\hline $\begin{array}{l}\text { 9.Verilen eğitimin değerlendirilmesi için sınıf veya okul çapında tasarım yarışmaları } \\
\text { düzenlenmeli }\end{array}$ & 1 \\
\hline 10.Proje temelli ders içerikleri oluşturulmalı & 1 \\
\hline 11. Araştırma ve geliştirmeye yönelik proje çalışmalarına yer verilmeli & 1 \\
\hline Toplam & 33 \\
\hline
\end{tabular}

Mezun çalışma grubunun, moda tasarımı eğitiminin daha etkili ve yeterli hale getirilebilmesi için neler yapılabilir? sorusuna verdikleri yanıtlar sonucunda on bir kategori ortaya çıkmıştır. Lisans düzeyi mezunu 35 katılımcıdan 23 kişi yanıtlayarak \% 65,7 oranında bir katılım sağlanmıştır. Moda tasarımı sanat eğitiminin daha etkili ve yeterli hale gelmesinde, en yüksek frekansa sahip yanıtların, okul dışı staj, sektör, tasarımcı vb. işbirliğine dayalı eğitime yer verilmelidir olduğu görülmektedir. Yine yüksek frekansa sahip yanıtlara göre, güncel ders içeriklerinin oluşturulması ve daha fazla sanatsal uyaranla bir araya gelebilecekleri müze, sanat galerisi vb yerlere geziler düzenlenmesi, uygulamalı eğitime ağırlık verilmesi, uzmanlaşmaya dayalı bir program yapısı oluşturulması, tasarımların analizi çalışmalarına yer verilmesi moda tasarımı eğitiminin etkili ve yeterli hale gelmesinde katılımcılar tarafından önerilen yanıtlar olmuştur.

\section{TARTIŞMA VE SONUÇ}

Bu çalışmanın amacı, Türkiye'de lisans düzeyinde moda tasarımı programlarında verilen sanat eğitimini, yurtdışında moda tasarımı lisans programlarında verilen sanat eğitimiyle karşılaştırarak, sektörde çalışan moda tasarımı lisans düzeyi mezunların sanat eğitimine ilişsin görüşleriyle değerlendirmek ve moda tasarımı alanına yönelik sanat eğitimi önerisi geliştirmektir.

Türkiye ve yurtdışında lisans düzeyi moda tasarımı eğitiminde verilen sanat eğitimi derslerine yönelik gerçekleştirilen incelemede, zorunlu sanat eğitimi derslerinin benzerlik gösterdiği görülmüştür. Zorunlu ve seçimlik ders sayıları ve seçimlik ders AKTS'nin toplam AKTS' ye oranına ilişkin yapılan incelemede ise, Türkiye' de moda tasarımı lisans programlarında sunulan seçimlik ders sayısı ile seçimlik ders AKTS' sinin toplam AKTS içerisindeki oranı, yurtdışında lisans moda eğitimi veren üniversitelere kıyasla daha yüksek orana sahiptir. Bu bulgu, Türkiye'de lisans moda eğitiminde verilen sanat eğitiminin, yurtdışında moda eğitiminde önde gelen üniversitelerden daha 
iyi yapılandırıldığına ilişkin bir resim oluşmaktadır. Ancak, yapılan incelemelerde, Türkiye'deki ve yurtdışındaki eğitim müfredatları arasında farklılıklar tespit edilmiştir. Yurtdışında moda tasarımı eğitimi müfredatı kadın giyim, erkek giyim, çocuk giyim, iç giyim, triko tasarım, moda pazarlama gibi alanlarda uzmanlaşmaya dayalı olup moda endüstrisi ağı, stajlar ve proje çalışmaları ile esnek ve kapsamlı bir öğretim sunmakla birlikte, üniversitelerin çeşitli moda markaları ve moda tasarımcılarıyla işbirlikleri olup, eğitimin yaklaşık yüzde ellisini, öğrencilerin bu marka ve tasarımcılarla gerçekleştireceği proje çalışmaları ve stajlar oluşturmaktadır.

Lisans düzeyi mezunlar iş pozisyonlarının gerektirdiği yeterlikleri çözüm üretme, yenilik, yorumlama, değerlendirme ve yaratıcılık olarak yanıtlamıştır. Mezunların iş pozisyonlarının gerektirdiği temel nitelikler için verdikleri yanıtlar sektörün üst düzey düşünme becerilerine sahip nitelikte çalışanlara gereksinim duyduğuna işaret etmektedir.

Araştırmaya katılan mezunlar iş pozisyonunun gerektirdiği çözüm üretme, yenilik, yorumlama, değerlendirme ve yaratıcılık, yeterliklerinin alınan eğitim ile kazandırıldığ görüşündedir.

Araştırmaya katılan lisans düzeyi mezunların moda tasarımında sanat eğitiminin daha etkili ve yeterli hale gelmesi için görüşleri: okul dışı sektör, tasarımcı vb ile işbirliğine dayalı eğitime yer verilmeli, uygulama ağırlıklı ders içerikleri oluşturulmalı, fuar, sergi, sanat galerisi, müze vb yerlere geziler düzenlenmeli, güncel tasarımcılar ve hazır giyim sektörünün çalışma biçimleri incelenmeli ve müfredata eklenmeli, uzmanlaşmaya yönelik bir program yapısı ve ona uygun dersler ve içerikleri geliştirilmeli, olmuştur.

Araştırmacı tarafindan gerçekleştirilen incelemede, araştırma bulgularıyla benzer bulgulara sahip çalışmaların olduğu görülmüştür. Başaran da (2013: 96) moda resmi dersi öğretim programını öğretim elemanı ve öğrenci görüşleri 1şı̆̆ında değerlendirdiği çalışmasında, okul dışı sektör ve tasarımcı işbirliğinin gerekliliğini moda resmi dersi için ifade etmektedir.

Uyar (2006: 136) Ankara ilinde bulunan üniversitelerde moda tasarımı eğitimini incelediği çalışmasında, öğrencilerin okullarına tasarımcı ve sektör çalışanının gelmediği ve sektörle işbirliğini yeterli görmedikleri bulgusuna ulaşmaktadır. Uyar'a göre moda tasarımı alanında çalışacak öğrencilerin, bu kişilerin tecrübelerinden faydalanması gerektiği düşünülmektedir. Bunun için de sektörle sürekli işbirliği sağlanmalıdır.

Soysaldı ve Balkanal (2011: 572) Tekstil Yüzey Tasarımı ve Eğitimi Programlarının İncelenmesi başlıklı çalışmasında, tekstil ve moda tasarımı lisans programlarında yeterli uzmanlaşma alanlarında eğitim verilemediğinin altını çizmektedir. Tekstil ve moda sektörüne başarılı tasarımcılar yetiştirmek için önlisans ve lisans programlarında üretim alanlarına göre (lif ve iplik tasarımı-yüzey tasarımı-giysi tasarımı) özel uzmanlık alanları (dokuma, boya, iç giyim, ev tekstili vb) oluşturarak eğitim verilmelidir (http6).

Türkiye'de lisans düzeyinde Moda Tasarımı sanat eğitiminin, yurtdışında verilen moda tasarımı sanat eğitimiyle karşılaştırılarak, sektörde çalışan mezun görüşleri 1şı̆̆ında değerlendirildiği çalışmada, sanat eğitimin özellikle uygulama ve etkinlikler temelinde eksik görüldüğü sonucuna ulaşılmaktadır. Mezunların daha etkili ve nitelikli sanat eğitimine ilişkin görüşleri, yurtdışında moda tasarımı eğitiminde önde gelen Moda Teknoloji Enstitüsü, Saint Martins Moda Okulu, ESMOD, Marangoni Enstitüsü ve Bunka Moda Koleji'nde uygulanan eğitim modeline işaret etmektedir. Çalışmanın bulgularıyla, profesyonellerin ve sektörün paydaş olacağı proje, saha uygulamaları, staj, teknik gezi ve etkinlikler ile yapılandırılmış bir sanat eğitimi önerilmektedir.

\section{KAYNAKÇA}

[1] Aslan, C. (2011). Soru Sorma Becerilerini Geliştirmeye Dönük Öğretim Uygulamalarının Öğretmen Adaylarının Soru Oluşturma Becerilerine Etkisi. Eğitim ve Bilim. Cilt 36, Sayı 160, 236-249. 
PINAR CINAR / ISEC2021 Sakarya- Turkey

[2] Aslan, C. (2012). Dil ve Edebiyat Öğretiminde Üst Düzey Düşünme Becerileri. Doktora Ders Notları.

[3] Arı̆ , A. S. (2014). Türkiye'de Kız Enstitüleri: Gelenekten Geleceğe. Hacettepe Üniversitesi Türkiyat Araştırmaları Dergisi. Mart 1, 193-216.

[4] Aygül, Z., Özüdoğru, Ș. (2014). Moda Tasarımcısı Olmak: 'Yeni Mezun Moda Tasarımcıları Üzerine Söylemsel Bir Araştırma'. Mediterranean Journal of Hümanities, IV/2, 35-49.

[5] Baki A.; Gökçek T. (2012). Karma Yöntem Araştırmalarına Genel Bir Bakış. Elektronik Sosyal Bilimler Dergisi. Cilt 11, Sayı 42, 1-21.

[6] Başaran, B., Şirin, N. (2013). Moda ve Tekstil Tasarımı Öğretim Programında Görsel Sanatlar Eğitimi. İdil, cilt 2, sayı 6, 71-99.

[7] Başaran, B. (2019). Moda Resmi Ders Öğretim Programının Öğretim Elemanı ve Öğrenci Görüşleri Işığında Değerlendirilmesi (Yayımlanmamış Doktora Tezi). Necmettin Erbakan Üniversitesi, Konya, Türkiye.

[8] Bilgen, S. (2002). Moda Tasarımı Eğitimi ve Türkiye'deki Uygulamalar. Sanayide Yeni Ufuk ESO Dergisi, 22, s.30.

[9] Choi, K.H. (2011). A Comparative Study on Fashion Design Education in Europe and Korea. Journal of the Korean Society of Clothing and Textiles. Say1:35, 1199-1214.

[10] Çınar, P. (2020). Moda Tasarımı Alanınında Nitelikli Bireylerin Yetiştirilmesine Yönelik Sanat Eğitimi İçeriğinin Değerlendirilmesi ve Geliştirilmesi (Yayımlanmamış Doktora Tezi). Ankara Üniversitesi, Ankara, Türkiye.

[11] De Girvy, V. (1999). Moda ve Sanat. Kültür Sanat ve Antika Dergisi, 12, 8-12.

[12] Faerm, S. (2012). Towards a future pedagogy: The evaluation of fashion design education. International Journal of Humanities and Social Science. Vol: 2/23, 211-219.

[13] Gürüz, K. (2003). Dünyada ve Türkiye'de Yükseköğretim Tarihi ve Bugünkü Sevk ve İdaresi Sistemleri. Ankara: YÖK Yayınları.

[14] İşler, H., Demir, B. ve Üştün, S. (2012, Haziran). 'Endüstriyel Gelişim Sürecinin Mesleki ve Teknik Eğitim Üzerindeki Etkisi’ Ulusal Meslek Yüksekokulları Çalıştayı ve Öğrenci Sempozyumu. (s.232-242). Ürgüp.

[15] Karasar, Niyazi. (2005). Bilimsel Araştırma Yöntemi. Ankara: Nobel Yayınevi.

[16] Marshall, T. (2009). Designing design education. Form, 224.

[17] Uyar, Ş. (2006). Ankara ilinde bulunan üniversitelerde moda tasarımı eğitimi (Yayımlanmamış Yüksek Lisans Tezi). Gazi Üniversitesi, Ankara.

[18] Yıldırım A.; Şimşek H. (2008). Sosyal Bilimlerde Nitel Araştırma Yöntemleri. Ankara: Seçkin Yayinevi.

[19] http1. http://www.fitnyc.edu/fashion-design/index.php (Erişim Tarihi: 05.02.2018).

[20] http2. https://www.arts.ac.uk/colleges/london-college-of-fashion/courses/undergraduatecourses (Erişim Tarihi: 10.02.2018).

[21] http3. https://www.esmod.com/en/fashion-design/programs/courses-of-study-in-fashiondesign/ (Erişim Tarihi: 17.02.2018).

[22] http4. https://be-prod.ggeedu.it/marangoni/IM_PS_Fashion-Design_3Y_Course_MI-FI.pdf (Erişim Tarihi: 22.02.2018).

[23] http5. https://www.bunka-fc.ac.jp/course/fukusyokusenmon-katei/ (Erişim Tarihi: 28.02.2018).

[24] http6. Soysaldı, A.; Balkanal, Z. (2011). Tekstil Yüzey Tasarım ve Eğitim Programlarının İncelenmesi. (ss. 568-574). N. Bayraktar, T.İ. İlisulu, E. Tataroğlu ve P. Türkdemir (Editörler), 1. Sanat ve Tasarım Eğitimi Sempozyumu. http://gsf.baskent.edu.tr/kw/upload/324/dosyalar/bildiri_kitap_2011.compressed_v1.pdf?birim= 324\&menu_id=19. Erişim tarihi: 20.01.2019 